\section{Disaster looms for Bombay}

\section{New DelhI}

PROMPTED by a warning from the World Health Organisation (WHO) in Geneva, the Indian Council of Medical Research (ICMR) is launching a campaign to fight the spread of AIDS in Bombay. WHO experts have told the council that some 60,000 AIDS patients will require hospitalization in India in the next five years and that Bombay will be worst affected.

According to WHO, the rates of infection in Bombay are "unparalleled". ICMR's own survey in Bombay's red-light district shows that 30 per cent of prostitutes are infected with human immunodeficiency virus (HIV). In WHO's opinion, HIV is being transmitted heterosexually in India.

Based on estimates that there may be 250,000 people infected with HIV in the large cities of India, WHO has warned ICMR that in 1995, "there would be close to 60,000 cumulative AIDS cases even if no new HIV infections occurred after 1989". Although ICMR's own surveillance centres have so far detected only about 3,200 seropositive cases, Dr A. S. Paintal, its director general, says "no one must think for a moment that the predictions of WHO experts are exaggerated". Studies by ICMR show that some 60 per cent of Indian women attending antenatal clinics suffer from inflammations. "The prevalence of inflammation is conducive for transmission of AIDS", says Usha Luthra, deputy director general of ICMR.

According to Paintal, WHO has forecast that "every third housewife of Bombay will be found to be infected with HIV at antenatal examination". Declaring that India is entering a "disaster phase",

Paintal has called for a massive public education campaign and promotion of safer sex practices. Educational institutions, women's organizations and business houses have been asked to assist ICMR in its campaign. Newspapers have been urged to donate space for educational messages to the people of Bombay.

The Ministry of Health, which suffered a 10 per cent cut in its budget this year, is worried about the lack of facilities for people suffering from AIDS. "We had asked ten major hospitals in the country six months ago to create special wards and be ready to treat AIDS patients", says Health Secretary N. Srinivasan. But so far not a single hospital has complied. Last month, the All-India Institute of Medical Sciences, New Delhi's leading medical facility, turned away two people with AIDS because its staff was scared to handle them.

K. S. Jayaraman - WHO says that 8-10 million people worldwide are infected with HIV, updating the previous estimate of $6-8$ million. The revision follows a detailed analysis of HIV serological data for 1988 and 1989. The new figures reflect the worsening of the epidemic through heterosexual transmission in sub-Saharan Africa, where 5 million people (one in 40 adults) are now thought to be infected, and in Asia. HIV was introduced into Asia only in the mid$1980 \mathrm{~s}$, but there are now about 500,000 infected people in the continent.

Michael Merson, director of WHO's Global Programme on AIDS, warns that further revisions are likely, as the HIV prevalence in Latin America and Asia expands rapidly, and the African epidemic continues.

P.A.

\title{
SPACE POLICY
}

\section{Advice from the in-crowd}

\section{Washington}

FACING renewed criticism of its management and projects, the National Aeronautics and Space Administration (NASA) last week announced the membership of a high-level advisory panel, formed at the behest of vice-president Dan Quayle and the National Space Council, to review the future of the US space programme.

The panel will be headed by Norman Augustine, chairman of Martin Marietta, an aerospace corporation with many NASA contracts. Of the 11 other members, five are from the aerospace industry, two are scientists (James Baker of the Joint Oceanographic Institutes and the Jet Propulsion Laboratory and Louis Lanzerotti of AT\&T Bell laboratories) and two are former NASA officials.

Although the panel members are considered knowledgeable and outspoken, few observers expect that they will suggest major changes in NASA's current system. "This is not a panel that is going to recommend getting rid of the space station, the shuttle or Moon/Mars. These are the elder statesmen of the aerospace industry, not boat rockers", says space analyst John Pike of the Federation of American Scientists. Meanwhile it was reported last week that tests in 1981 had revealed the optical error in the main mirror of the Hubble Space Telescope, but the tests had been discounted because more sophisticated, but now suspect, tests showed no problems. So far there is no evidence that the tests were intentionally suppressed (as had been claimed in the Challenger disaster), but investigators are looking into a 700 per cent cost overrun at contractor Perkin-Elmer during the construction of the mirror.

Christopher Anderson

\section{Forensic tests proved} innocent

\section{Washington}

As expected, the forensic use of DNA tests (genetic fingerprinting) has won the approval of the Congressional Office of Technology Assessment (OTA). In a report* released last week, DNA tests are described as "reliable and valid when properly performed and analysed by skilled personnel".

Genetic fingerprinting has already been admitted into evidence in at least 185 trials and its validity has never been in serious doubt. All the big disputes over the tests such as the furore at the Castro murder trial (see Nature 339, 50115 June 1989) have revolved around the way tests are performed and interpreted.

The report does not attempt to answer the vexing questions of the interpretation of DNA test data. Estimates of the probability that two samples come from the same person depend on knowledge of how similar people normally are - that is, on how genetic markers are distributed in the population. Because people form many different subgroups, and genetic markers are not mixed at random, several court cases are now challenging the assumptions under which a 'match' between two samples was declared.

Alun Anderson

*Genetic Witness: Forensic Uses of DNA Tests, OTA-BA-438 (Washington, DC: US Government Printing Office, July 1990) AIDS RESEARCH

\section{Mice or men? San Francisco}

A NOVEL project that will use mice implanted with parts of human immune system to test new AIDS drugs has won a \$3.2 million, five-year contract for SyStemic, Inc. of Palo Alto, from the US National Institute of Health. The mice can be infected with HIV and are the only non-human animal to contain functioning human tissues and organs. SyStemics expect that use of the mice will allow faster predictions of how humans may respond to new drugs than other animal models or cell cultures currently provide.

SCID-hu (severe combined immunodeficient-human) mice lack an immune system of their own because of a genetic defect and have had human blood cell precursors, thymus and lymph nodes surgically transplanted into them. They develop functioning human immune systems and when infected with HIV, then treated with AIDS drugs AZT or ddl, their transplanted tissues respond much like those of human patients.

The company began to offer testing of potential AIDS drugs to biotechnology and pharmaceutical firms earlier this year; but this is their first government contract. "We take this as an endorsement of the validity of the model," said C. W. Dickey, a SyStemics director.

Elizabeth Schaefer 